\title{
X.-Notes on a Picture representing the Three Children of Philip King of Castile, in the possession of Evelyn Philip Shirley, Esq., F.S.A. By George Scharf, Esq., F.S.A.
}

Read May 23rd, 1867.

THE curious triptych figured in Plate XV. appears to have been, in the first instance, a gift from Philippe le Beau and Jeanne la Folle, parents of the children therein represented, to King Henry VII., to commemorate a visit which they unexpectedly paid to this country at the beginning of 1505 .

The triptych has been ascertained, by means of a brief entry in an inventory taken for Henry VIII. of goods and furniture deposited in his Palace of Westminster, to have been royal property in 1542. It is there denominated "a folding table," and occurs at the end of a long series of royal portraits.

The triptych itself consists of three arched panels, uniform in size and shape, placed side by side and joined by hinges so ingeniously contrived as to permit them to be folded and laid quite flat one upon the other. Each panel is surrounded by a deeply-moulded frame of the same piece with the rest, and measures $1 \mathrm{ft}$. $2 \frac{7}{8}$ in. in height, $7 \frac{7}{8}$ in. in width, and $\frac{3}{4}$ of an inch deep. The entire length, when fully open, measures $1 \mathrm{ft}$. $11 \frac{5}{8} \mathrm{in}$. At the back of the central panel is attached a staple or flat hook for the purpose of suspension on the wall.

Each panel contains the half-length portrait of a child, surmounted, in the round-headed space above, by a shield of arms bearing the archducal crown of Austria." The names of these three children are inscribed over their heads in thin white letters of an ornamental character on a flat pale grass-green background. They read as follows, from the left to right-_"Madame Leonora," "Duc Charles," "Madame Ysabeau." We, therefore, have before us in all probability the earliest known portraits of the Emperor Charles the Fifth and of his two sisters Leonora and Isabella. Leonora, placed as the elder on his

* Charles's coat is quarterly of four. 1. Austria. 2. Burgundy ancient. 3. Burgundy modern. 4. Brabant. Surtout Flanders. In chief a label argent. The shield is surrounded by the collar of the Golden Fleece. The arms above the two sisters are the same, with the omission of the label, and each occupies the sinister side of a lozenge party per pale, the dexter side in each case being left blank.

VOL. XIII. 
right hand, was born at Louvain in 1498. She married, first, in 1519, Emanuel, King of Portugal, and secondly, in 1530, Francis 1., King of France. ${ }^{a}$ She finally, in her widowhood, accompanied her brother in his retirement to the monastery of Yuste," and died in 1558, but a few months before him.

Charles, only known during his infancy as Duc de Luxembourg, was born at the Castle of Gand, in Flanders, 25th February, 1500.

Isabella (Ysabeau), or Elizabeth, born 1501, was married to Christian, King of Denmark, afterwards so ignominiously distinguished as the "Nero of the North." She shared her husband's misfortunes, and died prematurely in the Low Countries, January 20th, 1525. She became the mother of the three children whose portraits are contained in a royal picture still at Hampton Court Palace, also recorded in the Westminster Palace inventory, and which during the last century was engraved by Vertue, under the erroneous designation of the children of King Henry VII. ${ }^{d}$

This triptych, now the property of Evelyn Philip Shirley, Esq., of Lower Eatington Park, Warwickshire, was recently offered for sale at Willson's curiosity shop, in the Strand.

When Mr. Shirley first drew my attention to it, the names of the personages, combined with the peculiarity of this "folding" arrangement of the tablets, at once associated them in my mind with a curious, and hitherto puzzling, entry in the Westminster inventory of 1542, which stands in full, thus-

"Item, a folding table, with the pictures of the King of Castell's (Castile's) children."

The designation is easily explained when we remember that Philippe le Beau, son of the Emperor Maximilian, and husband of Jeanne la Folle, daughter of Queen Isabella, became King of Castile, in right of his wife, at the death of her mother, in November, 1504 .

To judge by the ages of the children here represented, and making due allowance for the fact that in these times painters always made children of high birth appear prematurely old-possibly to compliment them with an appearance of wisdom and depth of thought instead of innocence and simplicity-the por-

a Biographie Universelle, s. v. Eléonora, p. 10.

b Stirling's Cloister Life of Charles V. London, 1853, pp. 4, 142.

c Histoire Généalogique des Maisons Souveraines de l'Europe, par. M. V. . . , Paris, 8vo. 1812, ii. 74.

d See Archaologia, xxxix. 257.

e Prescott's History of Ferdinand and Isabella, edit. 1854, pp. 467, 477. 
traits belong to the year 1505 ; that is, during the period between the succession of Philippe to the crown and his embarkation from the Netherlands in January, 1506, to take possession of his new kingdom.

As a work of art, the triptych is not likely ever to have been held in any particular esteem. That such at least was the case during the period of its deposit at Westminster from 1542 to 1547 , may be gathered from the inventory above quoted, in which all paintings of superior artistic interest and value are distinguished by the addition of a "curteyne of yellow and white sarconette paned together" to protect them. In connection with this picture no such protection is recorded.

The style of painting is dry and timid, the colouring, especially of the flesh, chalky, but the folds of the draperies are well conceived, and bespeak the influence of a superior master. Some of the colours of the dresses appear to have been brightened by the application of fresh "glazings;" but the faces and hands, poorly enough drawn and modelled in the first instance, have escaped injury and reparation or improvement, to an unusual extent. As usual with pictures of the Flemish school, the golden ornaments, both chains, rings, and other articles of jewellery are entirely free from gilding, and are expressed chiefly by a pale yellow colour laid on with considerable thickness. The background also is of such a very pale hue that, at first sight, the thin white letters of the names upon it are almost entirely lost.

On the 8th of January, 1506, Philippe le Beau and Jeanne la Folle embarked on board a splendid and numerous armada, and set sail from Middelbourg, a port in Zealand. A furious tempest scattered the fleet soon after leaving the harbour ; but the King's ship, completely disabled, was driven into the English port of Weymouth. ${ }^{a}$ King Henry VII. on learning the misfortune of Philippe and his consort, promptly showed them every mark of respect and consideration. They were escorted in magnificent style to Windsor, and remained there under circumstances of dubious hospitality nearly three months. When the Flemish fleet had refitted and assembled at Weymouth, the royal pair once more embarked, and reached Corunna, after a prosperous voyage, on the 28th of April.

It may be deserving of incidental remark to note that from the circumstance of King Philippe's unexpected arrival in this country the illustrious house of Russell first rose into celebrity. The King and Queen of Castile on landing at Weymouth were munificently entertained till King Henry invited them to Court 
by Sir Thomas Trenchard, a resident in that part of the country. Sir Thomas had promptly summoned his neighbour and relation Mr. Russell, then newly returned from his travels, to wait upon them. King Philippe was so taken with his conversation that he desired he might enjoy his company to the Court, in which journey, " being much affected with his learned discourse and generous deportment," he recommended him to King Henry as a gentleman fitly qualified to serve him in some considerable station; and he was thereupon taken into great favour, and made one of the gentlemen of the Privy Chamber. ${ }^{\text {a }}$

Bacon, in his history of the reign of Henry VII., affords some interesting particulars of the intercourse maintained between the sovereigns during this sojourn at Windsor. The close of the visit is thus recorded :-

"Meanwhile King Henry (to draw out the time) continued his feastings and entertainments, and, after he had received the King of Castile into the fraternity of the Garter, and for a reciprocal had his son the Prince admitted to the order of the Golden Fleece, he accompanied King Philip and his Queen to the City of London; where they were entertained with the greatest magnificence and triumph that could be upon no greater warning. And as soon as the Earl of Suffolk ${ }^{b}$ had been conveyed to the Tower (which was the serious part) the jollities had an end, and the Kings took leave." c

In a former contribution to the Archæologia, describing some historical portraits, still preserved at Windsor Castle and Hampton Court Palace, I had invited attention to the great value, for the purpose of identifying the older portraits of the manuscript catalogue of pictures belonging to Henry VIII. in Westminster Palace in 1542. At that time, as only a very partial notice of this record had been made known, I ventured to urge the desirability of having the whole of that inventory, so far as related to the paintings and sculptures, carefully printed. Walpole, in his Anecdotes of Painting, had given a few extracts of some of the most characteristic entries, and Dallaway subsequently enlarged the selection in an appendix added to the first volume of his edition of the Anecdotes published in 1826. The earlier manuscript, 1542, is in the Record Office, Chancery Lane (vol. 160 of Miscellaneous Books of the Augmentation Records). The later MS., dated 1547, is in the British Museum, Harleian MS. 1419.

Speaking of this interesting document, Walpole observes : " In the Inventory

- Collins's Peerage, ed. 1779, i. 245.

b Edmund De la Pole, beheaded 30th April, 1513.

- Bacon's Historie of the Raigne of King Henry the Seventh, ed. 1622, p. 225.

axxix. 248, 264.

- Works of the Earl of Orford, 4to. 1798, iii. 55. 
in the Augmentation Office which 'I have mentioned, containing an account of Goods, Pictures, and Furniture in the Palace of Westminster, under the care of Sir Anthony Denny, Keeper of the Wardrobe, it appears that they called a picture a table with a picture; prints, cloths stained with a picture; and models and basreliefs they termed pictures of earth; for instance-

"Item, one table with the picture of the Duchess of Milan, being her whole stature.

"Item, one table with the history of Filius Prodigus.

"Item, one folding table of the Passion, set in gilt leather.

"Item, one table like a book with the pictures of the King's Majesty and Queen Jane," \&c.

In the "Old London" volume, consisting of papers read at the London congress of the Archaeological Institute, July, 1866, and published in the following year by Mr. John Murray, all the most essential pictorial items of this inventory were inserted in the pages of an essay which I contributed " on Royal Picture Galleries." To facilitate reference, these were arranged in alphabetical order, and the old spelling of the text, from the volume in the Record Office, was scrupulously adhered to.

Mr. Wornum has, however, since this period, in the completest manner possible, transferred the entire text of the British Museum MS. in its actual order, without change, comment, or addition of any kind, as an appendix to his valuable "Life and Works of Hans Holbein," 1867. There the items are numbered, and "the King of Castile's children" stands the fifty-third on that list.

Beyond this entry in the inventory of 1547 , although most of the royal pictures may be recognised, passing step by step through the collections of Charles I., James II., and Queen Caroline the Consort of George II., no further mention occurs of the triptych before us. Very imperfect records have been preserved of royal pictures during the reigns of Elizabeth and James I.; but in the year 1639 Charles I. had an elaborate account taken by Vander Doort of all the pictures belonging to the Crown, and to this we vainly turn for any entry or reference corresponding with portraits of the three children before us. All traces from this period had disappeared. In all probability this singularly arranged picture had been withdrawn from the royal collection during the reign of Queen Elizabeth when the Spanish name had sunk into such low esteem.

No brand or mark so generally found on pictures that belonged to Charles I. is traceable on any part of this triptych. When purchased by Mr. Shirley a thick coating of black lacquer covered the entire outside surface of the three panels, 
and evidently had been quite recently applied. This was removed in the hope of discovering some brand-mark, monogram, or heraldic device, such as usually appears on the external surface of "folding pictures" and the "sportelli" or wings of the larger altar-pieces in German and Italian churches. Nothing, however, was found beneath the black pigment. The wood itself was of the finest grained oak, and in excellent condition.

The costumes and physiognomy of the figures are curious and merit careful attention. Charles and his younger sister exhibit the Austrian lower lip strongly developed. Eleonora has the same peculiarity, but in a very much less prominent degree. Her portraits later in life, as Queen of France, retain the same character, and are, moreover, exceedingly pleasing. Her portrait, holding an orange, is described in the Westminster inventory of 1542 ; and a large and fine picture in similar costume to the last named, but holding a letter instead of an orange, is still preserved at Hampton Court Palace. In the collection of H.R.H. the Due d'Aumale is a small and well-executed portrait, also holding a letter. There is a similar picture in an oval frame at Longleat, the property of the Marquis of Bath, beautifully finished. A very interesting portrait of her in widow's weeds will be noticed presently. In the girl-portrait now before us she wears a large crimson head-dress with straight edges, covering the ears and terminating in front below in sharp angles. This head-dress is lined with yellow, and covers an arched edging of sharp points or plaiting encircling her natural rich brown hair, parted in the middle above the forehead. Her dress is dark brown, with sleeves close fitting to the elbows, and below them widened and turned up with deep rich crimson. The fair neck is seen through the opening of her square cut dress, covered with interlaced gold cords, and having in front a small circular ornament pendant from a thin cord necklace. A larger rope-shaped necklace, composed of red oval beads ribbed with gold cords, hangs low down from the back of her neck and passes through her right hand. A grey narrow girdle is fastened round her waist. No rings appear on her fingers or on those of her companions. The eyes are dark chesnut brown, and lips a soft pale crimson. The red on the cheeks is remarkably low down. The expression of the eyes, if not actually staring, is decidedly piercing. This plaiting between the hood and the hair may also be seen in the Windsor Castle portrait of Anne Boleyn having a golden letter $B$ and three pearls attached to the necklace. It appears likewise hanging over the shoulders of the portrait of Margaret Beaufort, Countess of

a In later days the Emperor always addressed her as "Madame ma meilleur sœur."-See Cloister Life of Charles V. By W. Stirling. P. 4. 
0
0
0
0
0
0
0
0
0
0

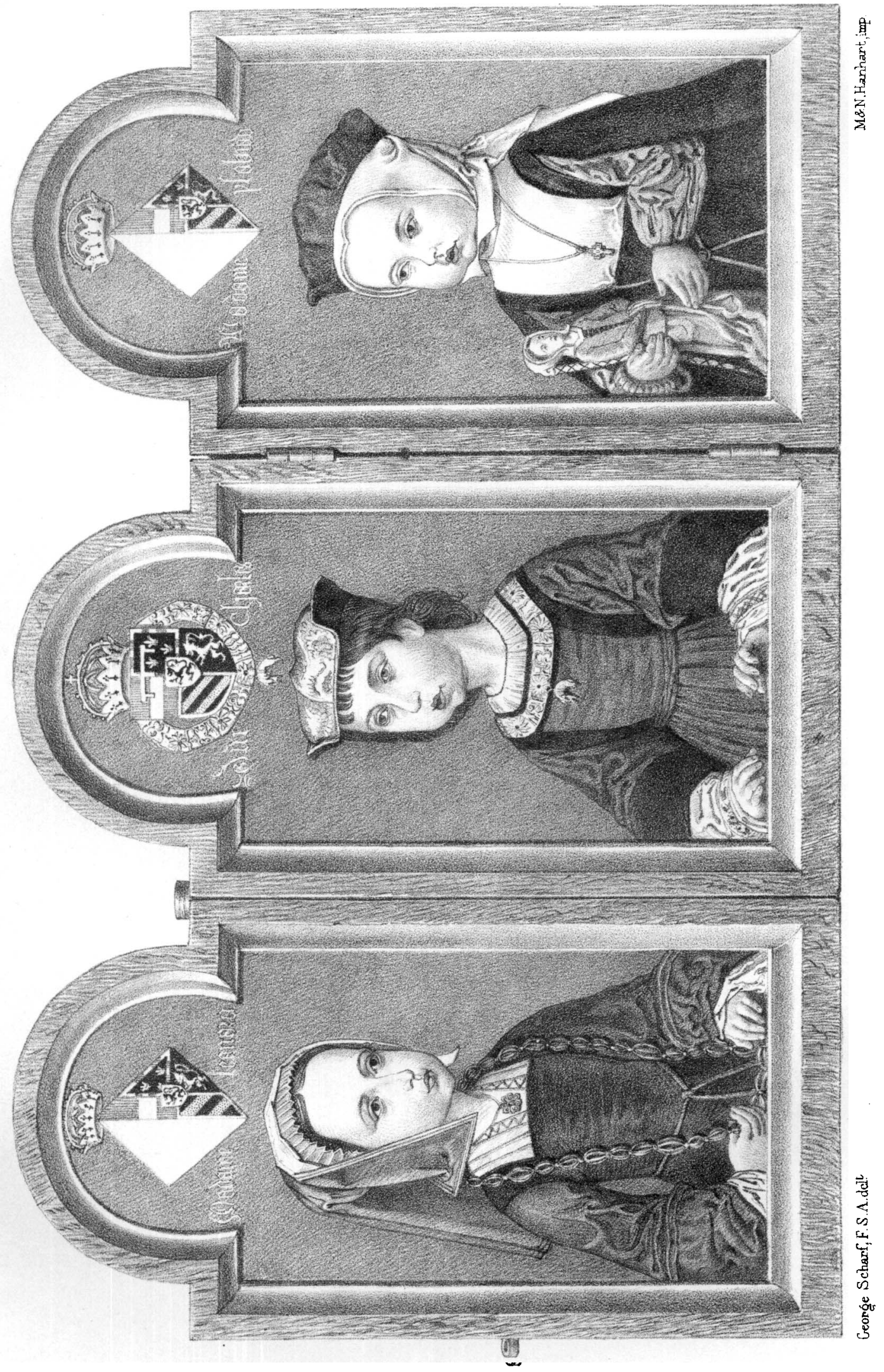

最 
Richmond and Derby, at St. John's College, Cambridge, No. 47 of the 1866 Portrait Exhibition at South Kensington, and a portrait of her aunt, Margaret, Archduchess of Austria, at Hampton Court, No. 298 of the catalogue.

The portrait of "Duke Charles," notwithstanding the peculiar formation of the mouth, is more agreeable in expression. The eyes are slaty blue, the hair dark rich brown, cut straight across the forehead, and hanging in long waving locks behind the ears. He wears a yellow tissue cap, with a slight peak at the top, and black lined flaps turned up over the ears. A similar cap to this occurs in his father's portrait at Windsor Castle, which is described in the Westminster inventory of 1542, and again, more fully, in King Charles's catalogue, $1639 .{ }^{\mathrm{a}}$

The boy's face is seen in three-quarters, turned to his right, towards his elder sister. He wears a deep crimson-coloured gown, faced with black, and yellow close-fitting under-sleeves, with narrow white cuffs at the wrist. A plaited white shirt appears round his neck, within the square-cut opening to his dress, and the collar of the Golden Fleece, composed of flints, steels, and sparks, with a small pendant fleece, lies on the upper broad black trimming in front. The collar is not gilded, but painted with clear yellow on a deep brown ground. He wears no other necklace, chain, or jewellery of any kind. His right hand nearly touches, as if just about to fall upon, the lower part of the frame, which is treated by the artist as a parapet or ledge, so frequently met with in Flemish and German pictures of the fifteenth century.

A youthful profile of Charles, on an imperial medallion, inscribed " REX Catolicvs," is engraved in Heræus' "Bildnisse der Regierenden Fürsten," plate 17, No. v. His grandfather Maximilian's head is on the obverse. The young king wears a cap similar in shape to that in the triptych, and the style of countenance, with straight cut hair along the forehead, bears considerable resemblance also to the earlier portrait. As Charles did not become Rex Catholicus till the decease of his grandfather Ferdinand, King of Spain, in January, 1516, this profile cannot exhibit him younger than sixteen years of age. Another portrait of this early beardless period, a medallion carved in boxwood, and now preserved in the British Museum, has been already described in a former contribution to the Archaologia. ${ }^{b}$ It is inscribed, CHARLES $\cdot \mathbf{R}^{\cdot} \cdot \mathbf{D E} \cdot$ CASTILLE $\cdot$ LEEON GRENADE' ARRAGON ' NAVERRE' CECILIS.

The next portrait of Charles, in point of age, deserving of notice, is to be found

a Page 116, No. 43, of Vertue and Bathoe's edition.

b Vol, xxxix. p. 263. 
at Versailles, in a curious group of Maximilian I. and his family, No. 3094 of the catalogue. In this picture, a highly-finished miniature on vellum, he still appears as a boy with smooth chin, black cap, and square cut hair. A considerable advance in respect to age, although still with a beardless face, is the portrait of the Emperor, holding a sprig of rosemary, at Windsor Castle, already described in the Archaologia.

After this I would place an excellent little panel picture of the Emperor Charles, with delicate thin moustaches and slightly sprinkled beard on chin, at Knowle, in Kent. The left hand is boldly foreshortened, as frequently seen in the works of Van Cleeve, and in the portraits by Janet of Francis I. Here, however, the black hat is considerably reduced in size. The same peculiarities are observable in a small and delicately finished picture at Petworth House. Very similar in appearance and costume is the following:- A large medallion of Charles $\mathrm{V}$. in profile, to the left, wearing a small hat and pointed beard, with his hair gathered in round curls, instead of the long straight-combed hair of the earlier type, engraved in Collas, Trésor de Numismatique, folio, Paris, 1841. Choix de Medailles en Allemagne, pl. 21, No. 2. The face is turned to the left; only the shoulders are seen, wearing a gown and collar, with the golden fleece hanging at the neck by a short ribbon. It is regarded as the best and most authentic representation of the Emperor in maturity, and is dated aN. ET. XXXIII. The lower part of the ear is distinctly shown. The peculiarity of this face, but with more developed moustaches, a fuller beard, and more strongly marked ear, is repeated in a curious medallion, a wood carving at Vienna, showing the Emperor Maximilian with his two sons, Charles and Ferdinand. It is dated Moxxxx. ${ }^{b}$

This group corresponds with a picture that belonged to Henry VIII., and is entered in the Westminster catalogue, No. 16 of Mr. Wornum's reprint, in his Holbein volume, thus: "Th'olde Emperouer, th'emprouer that nowe is, and Ferdynando." It continued in the possession of the Crown to the reign of Charles I. and in his catalogue, taken in 1639, the following description was made of it: "Upon the door of the chair-room-the picture of Emperor Frederick, and his son Maximilian Primo, together with another picture, with a golden fleece about his shoulders ; all three in one piece. Little half figures. In a wooden frame." c

a Vol. xxxix. p. 263.

- See Arneth, Monumente des Cabinettes en Wien, fol. 1858, pl. i. No. 128, and pl. iv.

c Old London, pp. 288, 335. The above description is literally copied from the Harleian Manuscript. Bathoe, p. 119, no. 58, has not merely changed the punctuation, but altered the word Primo into Prince. He has also inserted measurements which do not appear at all in the original MS. There can be little 
The same profile, turned the reverse way, with more sharply-defined moustaches and beard, hair in larger curls, and hat considerably diminished, wearing a cloak with broad spreading collar, and holding gloves in his right hand, resting both arms on a cushion, is also in the collection at Vienna. See Arheth, $u b i$ supra, pl. i. No. 130, and pl. vi. page 87. It is carved in alabaster, and very remarkable as a work of art. The portraits of Charles V. are so numerous that it would be vain to attempt to particularise even those which may be held to represent the distinctive changes in his appearance. In these pages I can only endeavour to note the most leading portraits which exist of him bearing a positive date or some especial historical circumstances associated with the representation.

Of all the medallic portraits bearing a positive date, the finest and most characteristic personification of the emperor is the one engraved in Collas, pl. xx.

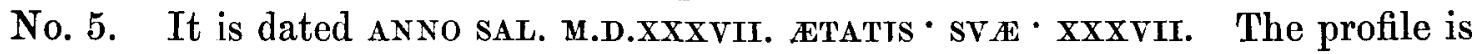
turned to the right. He wears a small bonnet, and holds a mace-like sceptre in his right hand, and a ball and cross in his left. The toison d'or hangs by a double cord on his breast.

The next record on a medal inscribed $\operatorname{ETAT} \cdot \mathrm{SV}_{\boldsymbol{E}} \cdot \mathrm{XLV}$., with ANNO $\cdot \mathrm{M.D.XXXXV} \cdot$ on the reverse, is published in Collas (plate xxi. No. 9), and exhibits a great change in regard to personal appearance. The cheeks have become hollow, the upper lip shrunk, and the nose consequently larger in proportion. The bonnet is fuller, with pendant earflaps, and the sleeves of his mantle are puffed round the shoulders in accordance with the fashion of the middle of the sixteenth century. The profile is turned to the left. The toison d'or hangs by a short ribbon in front.

A similar profile, but showing less of the figure, is engraved in Heræus, (pl. xxi. fig. 9). It belongs to the following year, and is inscribed CAROLVS $\mathrm{V} \cdot$ ROM ' IMP. anNo DNI M.D.XLVI. The head-dress is the same as in the preceding example, but the full collar of the toison d'or hangs round his neck.

The face, as seen in the last-named medals, corresponds with two full-length portraits of the emperor painted by Titian. One of these now at Madrid, and lithographed in The Madrid Museum by Cajetano Palmaroli, under the direction

doubt that this description is intended for the same picture as so. 16 of the Westminster catalogue. Some obvious errors in the 1639 catalogue will hereafter be noticed. In the present instance, the Emperor Frederick would be Frederick IV., husband of Leonora of Portugal, and father of Maximilian, thus shifting the names one generation back, and leaving one to infer that the third "picture" or portrait, would he Philippe le Beau instead of Charles $V$.

VOL. XLII.

$2 \mathrm{~K}$ 
of Madrazo, represents him as a tall, emaciated figure, standing in hat and small feather, with broad fur trimming to his mantle, resting his left hand on the black collar of a large dog. This picture formerly belonged to King Charles I. of England, and thus appears in the catalogue drawn up by Vanderdoort-." Done by Tichian. Item. The Emperor Charles V., brought by the King from Spain, being at length, with a big white Irish dog." a

The second portrait, a fine figure in black furred mantle, plain bonnet, and plain white falling collar, is seated in an arm-chair holding a paper in his right hand. The picture is in the Munich Gallery, No. 496 of the Pinakothek catalogue. The artist's name, Titianus, and the date MDxLvin. are inscribed on the background. It has been finely lithographed in The Munich Gallery.

A grand picture of Charles V. painted by Parmigiano (Francesco Mazzuoli) was exhibited at Manchester in 1857, No. 210 of the Exhibition catalogue. It is described by Vasari, and we learn from his pages that the portrait was completed without any appointed sitting, after seeing the Emperor dining in public, at Bologna, in the year 1530. (See Le Monnier's edition. Firenze, vol. 9. pp. 129 and 130.) There is no traceable inscription on the picture.

The last portrait of the Emperor that I can venture to name, devoid also of inscription, is a very fine whole-length by Titian. It is still in this country, and was exhibited at the British Institution, by Mrs. Henry Dawson, in 1858, No. 12 of the catalogue. ${ }^{b}$ He stands on a black and white pavement, wearing a richly ermined mantle, a plain black eap, and black hose and shoes. A dark green curtain is in the background, and a partridge stands at his feet. No date is observable on the picture, but the face $\mathrm{i}^{\mathrm{s}}$ decidedly younger than in the last few named examples. The introduction of the partridge would almost imply that it was painted in the Venetian territory. Mr. W. Stirling observes, in the preface to his Cloister Life of Charles $V$., that he has been unable to find any satisfactory contemporary portrait of the Emperor in his latter days. He, however, gives on the title page an effective woodcut from the fine print engraved by Eneas Vico.

With the portrait of the boy so fully before us, it has, I trust, been a matter of some interest to follow the course I have laid down, so as to compare the successive changes which the emperor's very singular physiognomy underwent,

a Page 86, No. 12, of Bathoe and Vertue's edition.

b See Artistic and Descriptive Notes on Pictures in the British Institution, Pall Mall, 1858. By G. Scharf, jun. p. 70 . 
and to watch those alterations even to the latest times when he became so faint a shadow of his former self in the monastery of Yuste.

It is now time, however, for us to turn to the remaining child-the younger sister Isabella, or Elizabeth - whose open expression and occupation, that of nursing a doll, contrasts so remarkably with the tenour and pursuits of her after life.

Even here, at this early period of her existence, the expression of her eyes can scarcely be said to be amiable. She grew up in later years to be heavy and roundfaced, indicative of indolence, with a short nose and full chin, similar in countenance to her maternal aunt, ${ }^{a}$ Catherine of Arragon, own sister to Jeanne la Folle, whose portraits are so well known, daughter to Ferdinand and Isabella.

There is also a remarkable likeness between this portrait of the girl with a doll and that of her own daughter, youngest of the three children of the King of Denmark, represented in the group at Hampton Court Palace. ${ }^{b}$ Among the pictures belonging to Henry VIII., we find in the Westminster inventory a second picture of this princess, taken after her marriage, thus described: "No. 29. Elizabethe of Austry, Quene of Denmark, with a curtain.". c

The picture, which is very small, appears still to be in the royal collection at Hampton Court Palace (no. 296 of the catalogue). It corresponds also with the following entry in Vanderdoort's catalogue of King Charles's pictrres taken at Whitehall in 1639 (page 115, no. 41 of Bathoe and Vertue's edition) :-

"A Whitehall piece. Item. The ninth, being Elizabeth, the Austria Queen of Bavaria, in a golden cloath habit, holding her two hands one over another."

This picture is one of four nameless portraits, similar in character, still at Hampton Court. In this solitary instance the eyes are of the required colour. The word Bavaria, however, is obviously an error for Denmark, since the rulers of the former were Dukes and Electors, and no Queen of Bavaria existed till very modern times. A portrait exists of this Queen Isabella in profile finely engraved by Jacob Binck bearing date 1523. It is placed side by side with that of her husband Christian II. She wears a French hood with a black veil falling down behind, and an elaborately wrought necklace. The dress is cut square to show the neck. Shields of arms supported by boys are introduced on

Anderson's Tables, p. $710, \mathrm{I}$.

c Old London, p. 290, No. 21. Wornum's Holbein, p. 383.

b Archocologia, xxxix. 257.

2 K 2 
each side resting upon columns. The artist's monogram is on the right hand base, and below in capital letters is inscribed

\section{ELIZABET · DANOVRM - REGINA \\ ET $\cdot$ CE $\cdot$ ARCHDVCIS $\cdot$ AVS $\cdot$ ET $\cdot$ BVR. $^{a}$}

Her portrait in later life, wearing a richly ornamented dress with high standing frilled collar round the neck, occurs on the reverse of a finely engraved medallion of her husband, Christian of Denmark. Her highly decorated costume resembles that of the reign of Queen Mary I. of England. The inscription round the edge is ISABELla $\cdot$ Mariana $\cdot \mathrm{CAR}$ (oli) $\mathrm{CA}_{\mathbf{A}}$ (e) $\mathbf{S}$ (aris) $\mathbf{S}$ (oror). ${ }^{b}$

In the catalogue of pictures belonging to King Charles, taken at Whitehall Palace in 1639, is the following curious and inconsistent description of a portrait evidently intended for this lady :-

"A Whitehall piece. The picture of the widow of King Christian II. of Denmark. She was sister to the Emperor Charles V. In a widow's habit, in a black and part gilded frame, so big as the life, half a figure." c

Isabella did not live to attain the condition of widowhood, and we find that the King, her husband, survived her thirty-four years. ${ }^{d}$

There is, however, no difficulty in identifying the picture above described. It is still at Hampton Court Palace, No. 916 of the catalogue, and represents not

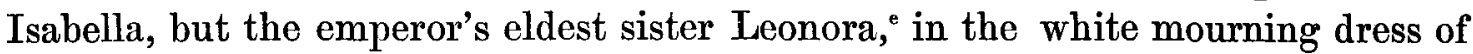
"La Reine Blanche" so peculiar to France, with which we are familiar by later portraits of Mary Queen of Scots. This remarkable picture is confirmed by a medal of Leonora in her "widow's habit," engraved in Heræeus, pl. xxv. No. 10. The corresponding picture of Mary of Hungary, the second surviving sister of the emperor, and also in a widow's habit, still remains in the royal collection. It has for many years lain under the erroneous designation of "the Countess of Lennox," No. 284 of the Hampton Court catalogue, and as such was removed to Holyrood Palace in 1864. ${ }^{\mathrm{g}}$

- Bartsch, viii. 294, 92 ; Nagler Künstler-Lexicon, s. v. Binck, p. 505.

b Heraus, pl. xvir. No. 21 ; and plate xxv. No. 14.

c Bathoe's edition, page 109, No. 10. In this and all other quotations from the Whitehall catalogue, I have corrected the text according to the original MS.

" It is somewhat remarkable that in two entries relating to this princess in King Charles's catalogue there should be such glaring oversight as to make her a queen of Bavaria, and the survivor of her husband.

e Ante, page 250.

f Vander Doort's Catalogue, printed by Bathoe and Vertue, p. 109, No. 9.

g See Old London, 1867, p. 374. 
To return to the early appearance of Isabella. We find her in the triptych before us represented as a chubby-faced child in a white coif entirely concealing the ears and hair, and showing nothing but the face. She wears a brown cap over the coif without fastenings of any kind.

The, dress is black, with under sleeves of a dark blue green and a broad square white linen covering the bosom, in front of which hangs a golden cross by a yellow cord round the neck. Her eyes are intensely dark chesnut brown. The complexion is fair, with very red lips. A plain grey girdle tied in front encirles her waist. The doll which she carries in her right arm is a feature of considerable antiquarian interest. Like most representations of such imitative objects in early art, it looks quite as real as the children themselves. The dress of the doll, consisting of a crimson robe, laced in front, long sleeves expanding at the wrists and concealing the hands, with a white hood and long plaited pendant behind, seems to belong to a somewhat earlier period than the date of the picture. A singular parallel of the portrait of a child carrying an elaborately dressed doll will be found at Hardwick Hall, in the curious portrait of Lady Arabella Stuart, at the age of 23 months, dated 1577, holding a completely-attired miniature lady in the left hand. The picture has been engraved by G. Cook in Miss Costello's Memoirs of Eminent Englishwomen, vol. i. p. 199. It was contributed by the Duke of Devonshire to the Portrait Exhibition at South Kensington in 1866, No. 422 of the catalogue.

The complete preservation of the materials, paint, wood, and metalparticularly the continued easy working of the singularly formed hinges - shows that this curious little monument has been spared many of the vicissitudes to which works of this nature are so constantly liable. It would be very interesting, although now beyond all hope, to ascertain the history of what befel our triptych between the reigns of Edward VI. and Queen Victoria, or to arrive at the circumstance which consigned it-perhaps continuously, in some narrow locality-to oblivion during the long period of 320 years. The outlines, in woodcut (Plate XVI.), will perhaps best serve to explain the manner in which the hinges worked, and how compactly the various parts were fitted together. 


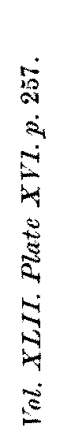

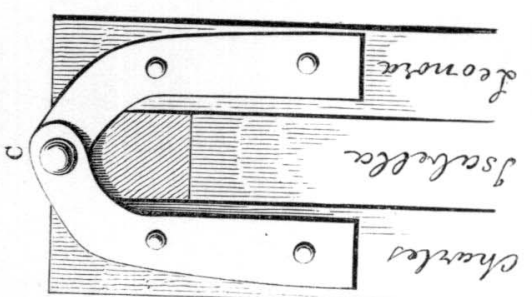

量

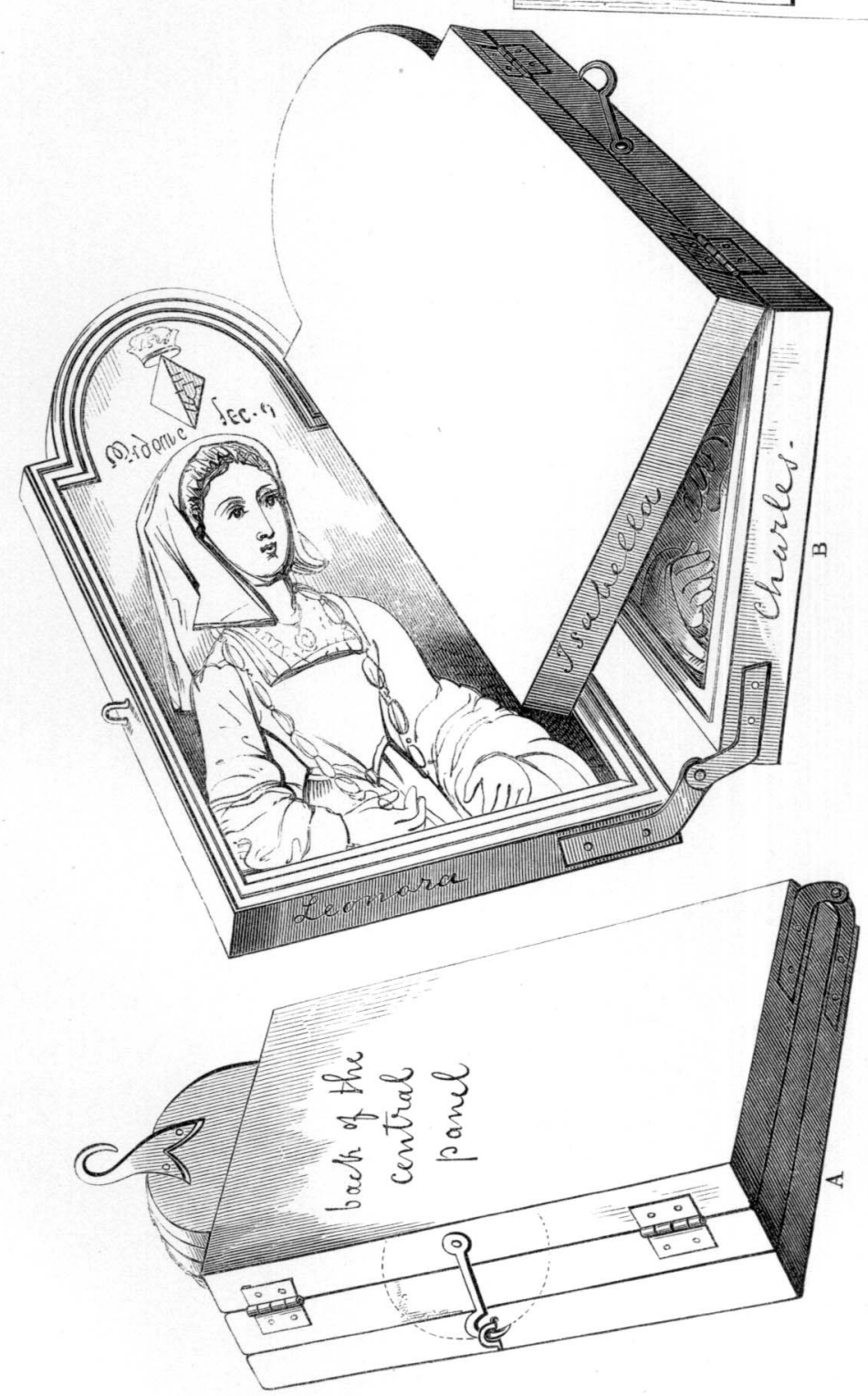

